\title{
Consequences of the Spanish Civil War for Entomology: A Quantitative Example of Abrupt Alteration in Scientific Research Dynamics
}

Carolina Martín Albaladejo, Museo Nacional de Ciencias Naturales Borja Sanchiz, Museo Nacional de Ciencias Naturales

\begin{abstract}
The effects of the Spanish Civil War (1936-1939) on entomology are evaluated quantitatively using publication-related data. The authors tested the hypothesis that all research results are equally affected by a period of severe disruption. This hypothesis is rejected, and they quantified the degree to which different research outputs were affected. The recovery of scientific production was fast; there was no major destruction of infrastructure. Exiles were not an important factor, and half of the entomologists were active both immediately before and just after the war. Important differences are found in the postwar period in relation to the international situation influencing Spain and the new organization of the state. A decrease is detected in publication in foreign journals, and there was less use of foreign languages. There was a growing importance of publications and scientists associated with the public sector. Conversely, there was a clear decline in research outside the public sector, and local learned societies recovered much more slowly than governmental institutions, which explains, for instance, the near-disappearance of publications in Catalan until the late 1950s. The study indicates that an abrupt social alteration will have a relatively minor impact on scientific production as long as there is a base of continuity of human and material resources and continuous government financial support.
\end{abstract}

Cientific research can be considered an accurate indicator of general social dynamics because $S$ it requires prolonged maintenance of structures that are easily altered by social changes. Knowledge growth depends on the activity of a small group of highly specialized scientists, a

Carolina Martín Albaladejo is a Research Scientist at the Spanish National Museum of Natural Sciences and Head of the History Studies Group recently established at the museum. Her research focuses on documentation and historical analysis of natural sciences in Spain, especially pertaining to entomology, museums, and scientific collections. Museo Nacional de Ciencias Naturales, CSIC, Madrid, Spain; carolina.martin@mncn.csic.es.

Borja Sanchiz is a Senior Research Scientist at the Department of Paleobiology of the National Museum of Natural Sciences, Spanish National Research Council. He works on paleoherpetology and evolutionary biology; more recently, he has been involved in the development of databases and knowledge management systems in order to standardize the historical aspects of scientific progress. Museo Nacional de Ciencias Naturales, CSIC, Madrid, Spain; mcnb105@mncn.csic.es.

Acknowledgments. We are particularly grateful to Eduardo Roldán for his critical comments and linguistic corrections that helped to improve the manuscript. This research was funded by Spanish government projects HAR2011-28621 and HAR201676125-P.

Isis, volume 108, number 2. (C) 2017 by The History of Science Society.

All rights reserved. 0021-1753/2017/0108-0006\$10.00. 
community drastically affected by short unstable periods of revolution and war. Furthermore, scientific production can be measured and the results analyzed quantitatively. ${ }^{1}$ This allows for hypothesis testing and removes much of the ideological bias that is adopted in some traditional historical and sociological accounts. Thus it is not only historically relevant to measure the impact of such drastic episodes on scientific production; it is also particularly important to recognize the characteristics of the subsequent recovery strategy.

As a pilot case for this numerical historical approach we have examined the Spanish Civil War (1936-1939) and its impact on Spanish entomology, the zoological study of insects. A combination of circumstances converge in this case, making it well suited for our purposes. In the first place, the Civil War was not only one of the most turbulent periods in Spanish history, but it also led to a substantial change in the country's administrative organization and the government's political ideology. ${ }^{2}$ Second, entomology, as it was practiced at the time, was a zoological discipline essentially engaged in taxonomic and faunistic research, with no industrial or economic relevance. Finally, the number of scientists and publications during this period is large enough to allow significant comparisons; extensive data gathering conducted in recent years makes it possible to carry out detailed bibliographic analyses. ${ }^{3}$ Thus, it is now realistic to test the general hypothesis that scientific production in every dimension was equally affected by this severely disruptive period. If this null hypothesis is rejected, it is then possible to quantify the degree to which different types of research output were affected.

The analysis of entomological contributions is made by using scientific publications, such as articles, monographs, and conference proceedings. There are other components involved in science - such as patents, unpublished reports, and the growth of museological collectionsbut the use of research groups and scientific documentation to examine the history of science is well established, and bibliometric analyses provide important indications of the scientific activity of each period. Furthermore, publication-related data have now become the main source for the evaluation of the scientific activity and quality of scientists, journals, and institutions. ${ }^{4}$ With respect to entomology, the general worldwide trend (see Figure 1) clearly shows the changes associated with the world wars in the twentieth century, indicating that these publication-related variables are suitable for the study of historical change.

In order to provide a meaningful comparison of entomological research in the pre- and postwar periods, we include a brief account of entomology's organizational structure, as well as noting the leading scientists and the chief institutions engaged in this type of research, for each period. It is the purpose of this article to compare the entomological research carried

\footnotetext{
${ }^{1}$ Yoshiko Okubo, "Bibliometric Indicators and Analysis of Research Systems: Methods and Examples," OECD Science, Technology, and Industry Working Papers, 1997, 1, http://dx.doi.org/10.1787/208277770603; and Élaine Gauthier, "Bibliometric Analysis of Scientific and Technological Research: A User's Guide to the Methodology," Working Papers-Science, Innovation, and Electronic Information Division, 1998, 8.

${ }^{2}$ See, e.g., Helen Graham, War and Its Shadow: Spain's Civil War in Europe's Long Twentieth Century (Brighton: Sussex Academic, 2012).

${ }^{3}$ Carolina Martín Albaladejo, Bibliografía entomológica de autores españoles (1758-1990) (Madrid: Museo Nacional de Ciencias Naturales, CSIC, 1994). For an update in CD-ROM format see Martín Albaladejo, Bibliografía entomológica de autores españoles (1758-2000), CD-ROM (Madrid: Museo Nacional de Ciencias Naturales, CSIC, 2005).

${ }^{4}$ Regarding the use of research groups and scientific documentation to examine the history of science see, e.g., Ignacio SuayMatallana, "La colaboración científica y los espacios de la química: Un estudio de caso español en la primera mitad del siglo XX," Revista Española de Documentación Científica, 2014, 37(4):e063, http://dx.doi.org/10.3989/redc.2014.4.1163. For bibliographic analysis as an indication of scientific activity see, e.g., José Luis Barona Vilar, Ciencia e historia: Debates y tendencias en la historiografía de la ciencia (Godella, Spain: Seminari d'Estudis sobre la Ciència, 1994). On publication-related data as a metric for evaluation see, e.g., Teodoro Luque-Martínez, “Actividad investigadora y contexto económico: El caso de las universidades públicas españolas,” Rev. Españ. Doc. Científ., 2015, 38(1):e076, http://dx.doi.org/10.3989/redc.2015.1.1135.
} 


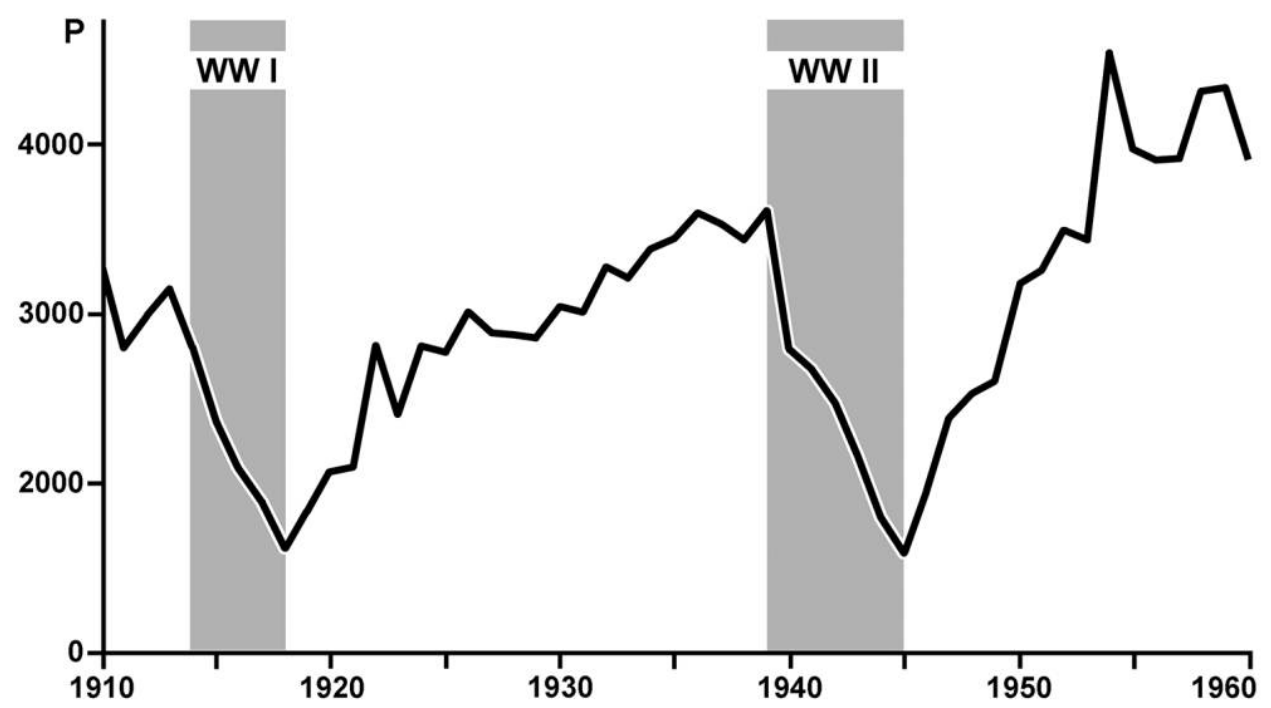

Figure 1. General worldwide trends in entomological publications $(\mathrm{P})$ per year during the period 1910-1960. Note the significant decrease in scientific production associated with the two world wars. Data from the Zoological Record® database. See http://scientific.thomson.com/products/zr / (accessed Dec. 2015 using the simple search [ST=Insecta OR SY=Insecta]).

out immediately before and after the Spanish Civil War, measuring production and activity in terms of publication-related data. The results are interpreted with reference to the main causal factors that could have had an impact during this period. Generalizations that might be valid in equivalent historical situations are made, and future comparisons involving different social parameters are suggested.

\section{METHODS, VARIABLES, AND SAMPLE SELECTION}

\section{Time Periods}

In order to provide a context of relative social stability for purposes of comparison, two periods of twenty-one years have been delimited before and after the Spanish Civil War (1936-1939). The first one (1915-1935) starts shortly after the year (1910) in which the first important governmental institution for the promotion of scientific research was founded-the Board for Advanced Studies and Scientific Research (Junta para Ampliación de Estudios e Investigaciones Científicas [JAE]) - and ends at the onset of the war. Scientific activity was much reduced during the war, with very few publications during this time; even work that was scheduled for publication was for the most part printed after the war ended.

The second period extends from 1940 to 1960 - that is, it begins immediately after the war and the year in which the JAE was transformed into another, equivalent institution, the Spanish National Research Council (Consejo Superior de Investigaciones Científicas [CSIC]). The end of this period coincides with the onset of the first National Stabilization Plan (1959-1967), which, with the end of the international boycott imposed on Spain and the country's incorporation into the United Nations (December 1955), entailed greater investment in research and a major reorganization of government. 
Two shorter periods of six years have been also considered in order to analyze the trends immediately before (1930-1935) and after (1940-1945) the Civil War.

\section{Publications}

Bibliographic data for both periods are taken from a recent compilation. ${ }^{5}$ This bibliography includes all the zoological works by Spanish scientists in which insects are part of the main subject of the study; it excludes works that deal with or mention these animals but have other objectives. That is, publications whose focus is chiefly agronomy, sericulture, or apiculture are not included, and neither are those on genetics or histology in which insects are merely experimental animals. Publications are dated according to their nominal cover year, not the year in which they were actually printed. In cases in which the series publication corresponds to several years, the earliest one is used.

Scientific publications mainly include articles, monographs, and conference proceedings. Besides total numbers, the following differentiating characteristics are considered:

-Journals versus other types of publication. While the current peer-review process was not typical in the periods studied, the editorial standards of acceptance for articles are assumed to have been different from those used for other publications in those years.

-National versus foreign journals. Articles by Spanish authors accepted in international journals are considered in general to have been prepared according to different criteria and more meticulously than those published in national ones.

-Government versus private academic journal editions. The editorial standards of governmental journals are considered to be different from the standards of journals managed by learned and local associations.

Citation analysis criteria are currently the most important indicators for assessing quality of scientists, journals, and institutions. Unfortunately, they cannot be considered for this study because such information is far from complete. In our case, a high proportion of Spanish local journals were not referenced or indexed in international databases: up to 41.4 percent for a sample of ten years taken at regular intervals between 1915 and $1960 .{ }^{6}$ Furthermore, taxonomic literature is normally cited only by the very few scientists who specialize in the same animal group, and the number of expected citations in general is not clearly related to the quality of the articles.

\section{Authors and Authorship}

The authorship of a publication refers to the printed list of coauthors. For the years studied here, the most frequent situation by far is single-author publication. However, sporadic collaborations ranging between two and four authors have been found (3.26 percent). Most comparisons and analyses-for example, productivity (publications per time interval) -will use the first author listed in multiauthored publications. Anonymous publications are counted as having single authors.

Three different groups are separately analyzed and compared for the periods studied. The first one (inXinN) considers all the Spanish entomologists, representing an approximation of the full entomological research potential of the country. The second (outXinN) excludes exiled scientists in the years that they were not active in Spain. Scientists in this situation include those who were working abroad before the war and returned to Spain afterward (only one

\footnotetext{
${ }^{5}$ Martín Albaladejo, Bibliografía entomológica de autores españoles (1758-1990) (cit. n. 3); and Martín Albaladejo, Bibliografía entomológica de autores españoles (1758-2000), CD-ROM (cit. n. 3).

${ }^{6}$ Carolina Martín Albaladejo, “Tendencias de la taxonomía entomológica española” (Ph.D. diss., Univ. Complutense Madrid, 2003).
} 


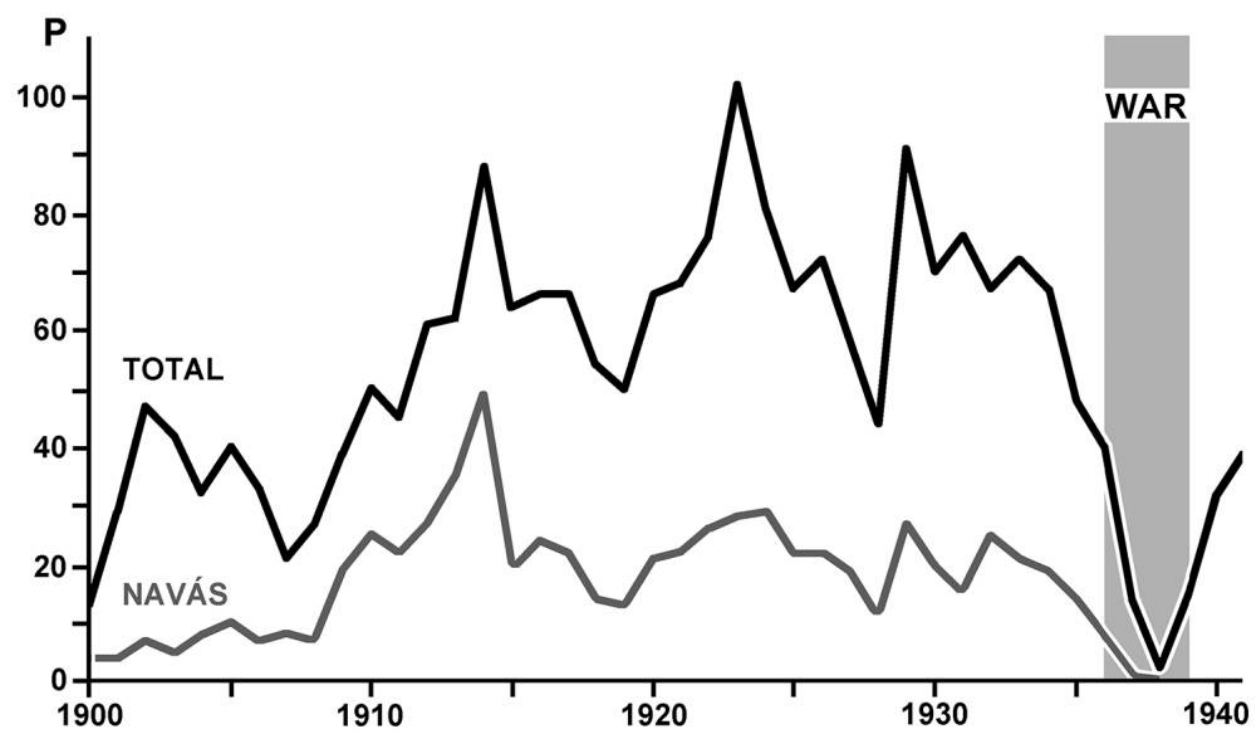

Figure 2. Entomological production (P) of Longinos Navás (gray line) in comparison to total Spanish production (black line). Posthumous publications are not shown.

case) and those who decided to leave the country as a result of the conflict, usually for political reasons (seven cases).

The third group (outXoutN) excludes the contribution of Longinos Navás, who figured in the second group. Navás was a Jesuit scientist who published at least 433 works between 1915 and 1935 (see Figure 2); his productivity of more than 20 publications per year represents about 31 percent of total national production in entomology in these years. Navás died during the war, in 1938, and he has to be considered separately because his extremely prolific output clearly makes him a statistical outlier for some variables. ${ }^{7}$

Continuity and generational change in the Spanish entomological research community have been estimated for twelve-year periods by means of comparisons between the first and second six-year half-periods: we looked at the percentages of scientists active only in the first, only in the second, or in both. Starting from 1915-1926, the periods are defined by displacing one year (e.g., 1916-1921, 1917-1922) until 1923-1934 and from 1940-1951 to 1948-1959. The Civil War years (1936-1939) are excluded, and the equivalent twelve-year period compares 1930-1935 with 1940-1945.

\section{Institutions}

In addition to looking at overall Spanish entomological activity, we treated the production of governmental versus nongovernmental institutions separately. The National Museum of Natural Sciences (Museo Nacional de Ciencias Naturales [MNCN]) is considered in some detail because it was the largest research institution in the country engaged in these studies.

The assignment of a publication to an institution is done by considering the affiliation of its first author. For the MNCN, two institutional relationships have been considered: staff and associated researcher. The first one includes official staff members and the second refers to unaffiliated scientists who frequently collaborated with the institution, in return receiving di-

\footnotetext{
${ }^{7}$ A detailed biography of this atypical entomologist is provided by Juan Jesús Bastero, Longinos Navás, científico jesuita (Zaragoza: Univ. Zaragoza, 1989).
} 
verse research instrumental benefits, personal economic aid, or payments for work performed (e.g., participation in expeditions, sampling, preparation of material).

\section{Customs and Research Conventions}

Unwritten norms, often taking the form of customs, characterize research schools. Comparisons are made concerning preferences with regard to publication venue, such as editorial nationality, language used, and so forth.

\section{Publication Contents and Research Agenda}

The thematic contents of the publications have not yet been analyzed, but there are preliminary indications that the pre- and postwar periods clearly differ in this respect. Based on data from the most important nongovernmental journal (in which Navás did not publish), the percentage of articles that included nomenclatural descriptions of new species or other Linnaean taxa was found to drop drastically, from 66.8 percent to 29.9 percent. ${ }^{8}$ This is probably a consequence of the new agenda of the new research organization established after the war, the Spanish National Research Council, in which applied science was promoted. ${ }^{9}$

Statistical analyses have been made using the software package PAST. ${ }^{10}$ The distributions of some variables differ from normality, and thus the nonparametric Mann-Whitney U-test was used for the comparison of means.

\section{SCIENTIFIC ADMINISTRATIVE STRUCTURES AND INSTITUTIONS}

Scientific activity served as a modernizing tendency in Spain during the first third of the twentieth century, reducing the research gap and underdevelopment inherited from the nineteenth century. The main official institution involved in this social change was the Junta para la Ampliación de Estudios e Investigaciones Científicas, founded in 1907 during the rule of King Alfonso XIII. Numerous studies have praised its achievements in scientific development and technical training. The Spanish Civil War interrupted this process of modernization; after the war, research in Spain was regulated by another large governmental institution, the Consejo Superior de Investigaciones Científicas. It is a matter of debate to what extent the CSIC is an inheritor and direct successor of the JAE or, instead, a completely different institution. In any case, it is historically unquestionable that the ideological orientations of the JAE and the early CSIC were quite different: the former was a liberal secular body, significantly influenced by Freemasonry through the Institución Libre de Enseñanza, while the latter tended to antiCommunist and nationalist-Catholicist thought. ${ }^{11}$ Many authors have explored the activities

\footnotetext{
${ }^{8}$ Entomological articles by Spanish authors in the bulletin of the Sociedad Española de Historia Natural numbered 115 (19151935) and 67 (1940-1960). The means of the yearly percentages of articles including new taxa are significantly different (MannWhitney U-test $\mathrm{p}<0.01)$ in the two periods.

${ }^{9}$ The foundational text of the Instituto Español de Entomología (1941) stated that "in the framework of pure research, [the Institute] can effectively favor the work entrusted to the services of health, agriculture, forestry, livestock, and the fight against damage caused by insects" (our translation). See Carolina Martín Albaladejo, Antonio Notario Gómez, and Alfonso V. Carrascosa Santiago, "El Instituto Español de Entomología (CSIC) y la multitud molesta," Asclepio, 2016, 68(1) (doi 10.3989/asclepio.2016.04).

${ }^{10}$ Øyvind Hammer, David A. T. Harper, and Paul D. Ryan, "PAST: Paleontological Statistics Software Package for Education and Data Analysis," Palaeontologia Electronica, 2001, 4(1):1-9.

${ }^{11}$ For praise of the JAE see Miguel Ángel Puig Samper, ed., Tiempos de investigación: JAE-CSIC, cien años de ciencia en España (Madrid: Consejo Superior de Investigaciones Científicas, 2007). For views as to the continuity or distinctiveness of the JAE and the CSIC see, e.g., Carlos Sánchez del Río, “La investigación científica en España y el CSIC,” Arbor, 1990, 135(529):61-73; and José Ramón Urquijo Goitia, "Ruptura y creación: Primeros años," in Tiempos de investigación, ed. Puig Samper, pp. $259-267$. Regarding the ideology of the JAE see Antonio Jiménez-Landi, Breve historia de la Institución Libre de Enseñanza (1896-1939)
} 


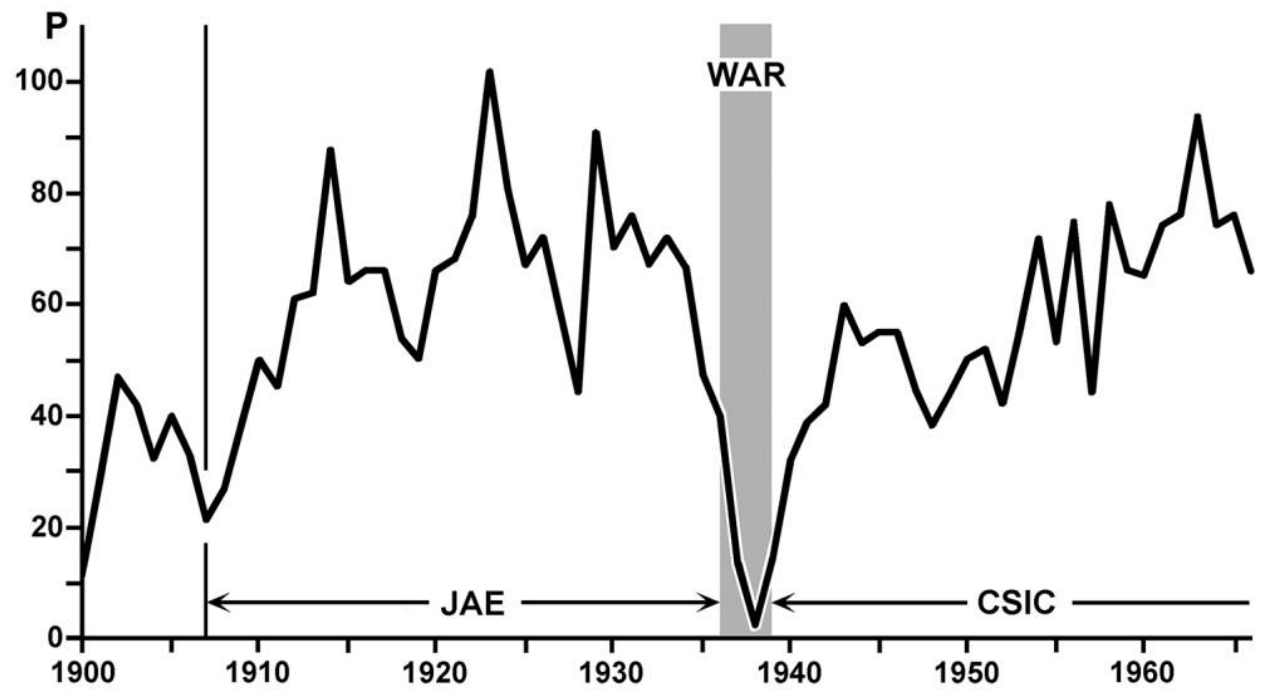

Figure 3. General trend of Spanish entomology, as indicated by the number of publications $(\mathrm{P})$ per year. The periods of activity of the major state scientific institutions (the JAE and the CSIC) are indicated.

promoted by these two organizations, such as their relations with other domestic and foreign institutions, budgets for infrastructure and equipment, patents registered, publications, andof particular interest-scholarship and grant programs. ${ }^{12}$

The National Museum of Natural Sciences, a mid-eighteenth-century institution that opened to the public in 1776, was largely responsible for the development of the natural sciences in Spain. The MNCN came under the jurisdiction of the JAE in 1910, with the entomologist Ignacio Bolívar serving as both director of the museum and vice president (and, as of 1934, president) of the JAE until the suppression of this institution. The steps taken in these years led to the increasing national and international prestige of the museum. ${ }^{13}$

During the JAE period, entomology at the MNCN was located in the museum's Section of Entomology under the leadership of Ignacio Bolívar, who occupied the position of Section Chief until 1922 and was succeeded by his son, Cándido Bolívar. After the war, in November 1939, the MNCN was assigned to the CSIC, but in 1941 its entomological section became an independent Spanish Institute of Entomology (Instituto Español de Entomología [IEE]), also under the auspices of the CSIC. ${ }^{14}$ The IEE acted as the de facto entomological department of

(Madrid: Tébar, 2010); on that of the CSIC see Alfonso Pérez-Agote, "Sociología histórica del Nacional-Catolicismo español," Historia Contemporánea, 2003, 26:207-237.

${ }^{12}$ Justo Formentín and María José Villegas, "Las pensiones de la JAE," in Tiempos de investigación, ed. Puig Samper, pp. 95-101; Formentín Ibáñez, Alfonso V. Carrascosa Santiago, and Esther Rodríguez Fraile, José Ibáñez Martín y la ciencia española: El Consejo Superior de Investigaciones Científicas (Madrid: CEU Ediciones, 2015); and José María Sánchez Ron, ed., La Junta para Ampliación de Estudios e Investigaciones Científicas 80 años después, 1907-1987, Vol. 1 (Madrid: Consejo Superior de Investigaciones Científicas, 1988).

${ }^{13}$ On the MNCN see Agustín J. Barreiro, El Museo Nacional de Ciencias Naturales (1771-1935) (Madrid: Museo Nacional de Ciencias Naturales, CSIC, and Editorial Doce Calles, 1992). On its increasing prestige see Luis Enrique Otero Carvajal and José María López Sánchez, La lucha por la modernidad: Las ciencias naturales y la Junta para Ampliación de Estudios (Madrid: Consejo Superior de Investigaciones Científicas, Residencia de Estudiantes, 2012).

${ }^{14}$ Alberto Gomis, "Mimbres para otro cesto: De la Sección de Entomología del Museo Nacional de Ciencias Naturales al Instituto Español de Entomología,” Boletín de la Real Sociedad Española de Historia Natural, Sección Biología, 2014, $108: 37-47$. 
Table 1. Basic Statistics for the Pre- (1915-1935) and Postwar (1940-1960) Periods

\begin{tabular}{|c|c|c|c|c|c|c|c|c|c|c|}
\hline \multirow[b]{2}{*}{ VARIABLE } & \multirow[b]{2}{*}{ Period } & \multicolumn{3}{|c|}{ inXinN } & \multicolumn{3}{|c|}{ outXinN } & \multicolumn{3}{|c|}{ outXoutN } \\
\hline & & $\Sigma \mathrm{N}$ & Mean & SD & $\Sigma \mathrm{N}$ & Mean & SD & $\Sigma \mathrm{N}$ & Mean & SD \\
\hline \multirow[t]{2}{*}{ Publications (Total) } & pre- & 1443 & 68.71 & 13.55 & 1425 & 67.86 & 13.50 & 994 & 47.33 & 9.90 \\
\hline & post- & 1166 & 55.52 & 11.45 & 1116 & 53.14 & 12.63 & 1114 & 53.05 & 12.71 \\
\hline \multirow[t]{2}{*}{$\begin{array}{l}\text { Publications } \\
\text { (Spanish ed.) }\end{array}$} & pre- & 1142 & 54.38 & 10.92 & 1142 & 54.38 & 10.92 & 958 & 45.62 & 10.26 \\
\hline & post- & 996 & 47.43 & 9.44 & 995 & 47.38 & 9.45 & 993 & 47.29 & 9.50 \\
\hline \multirow[t]{2}{*}{$\begin{array}{l}\text { Publications } \\
\text { (Foreign ed.) }\end{array}$} & pre- & 301 & 14.33 & 4.56 & 283 & 13.48 & 4.50 & 36 & 1.71 & 1.23 \\
\hline & post- & 170 & 8.10 & 4.31 & 121 & 5.76 & 5.31 & 120 & 5.71 & 5.36 \\
\hline \multirow[t]{2}{*}{$\begin{array}{l}\text { Articles (Total } \\
\text { journals) }\end{array}$} & pre- & 1334 & 63.52 & 13.78 & 1316 & 62.67 & 13.76 & 909 & 43.29 & 10.73 \\
\hline & post- & 1054 & 50.19 & 13.13 & 1005 & 47.86 & 14.58 & 1003 & 47.76 & 14.70 \\
\hline \multirow[t]{2}{*}{$\begin{array}{l}\text { Articles (Spanish } \\
\quad \text { journals) }\end{array}$} & pre- & 1050 & 50.00 & 11.51 & 1050 & 50.00 & 11.52 & 882 & 42.00 & 11.00 \\
\hline & post- & 898 & 42.76 & 11.72 & 898 & 42.76 & 11.72 & 897 & 42.71 & 11.69 \\
\hline \multirow[t]{2}{*}{$\begin{array}{l}\text { Articles (Foreign } \\
\text { journals) }\end{array}$} & pre- & 284 & 13.52 & 4.33 & 266 & 12.67 & 4.28 & 27 & 1.29 & 1.06 \\
\hline & post- & 156 & 7.43 & 3.96 & 107 & 5.10 & 4.76 & 106 & 5.05 & 4.81 \\
\hline \multicolumn{11}{|l|}{ Articles } \\
\hline \multirow[t]{2}{*}{ (Governmental) } & pre- & 324 & 15.43 & 7.62 & 325 & 15.48 & 7.55 & 254 & 12.10 & 7.91 \\
\hline & post- & 745 & 35.48 & 10.08 & 745 & 35.48 & 9.77 & 745 & 35.48 & 10.08 \\
\hline \multicolumn{11}{|l|}{ Articles } \\
\hline \multirow[t]{2}{*}{ (Nongovernmental) } & pre- & 726 & 34.57 & 11.15 & 727 & 34.62 & 11.10 & 628 & 29.90 & 10.08 \\
\hline & post & 153 & 7.29 & 4.29 & 154 & 7.33 & 4.19 & 152 & 7.24 & 4.31 \\
\hline \multicolumn{11}{|l|}{ Journals } \\
\hline \multirow[t]{2}{*}{ (Total number) } & pre- & 469 & 22.33 & 4.50 & 462 & 22.00 & 4.22 & 220 & 10.48 & 3.40 \\
\hline & post- & 361 & 17.19 & 5.36 & 335 & 15.95 & 6.27 & 335 & 15.95 & 6.27 \\
\hline \multicolumn{11}{|l|}{ Journals } \\
\hline \multirow[t]{2}{*}{ (Spanish, number) } & pre- & 267 & 12.71 & 2.43 & 267 & 12.71 & 2.43 & 195 & 9.29 & 2.90 \\
\hline & post- & 254 & 12.10 & 3.88 & 254 & 12.10 & 3.88 & 254 & 12.10 & 3.88 \\
\hline \multirow[t]{2}{*}{$\begin{array}{l}\text { Journals (Foreign, } \\
\text { number) }\end{array}$} & pre- & 202 & 9.62 & 3.06 & 195 & 9.29 & 2.94 & 25 & 1.19 & 0.98 \\
\hline & post- & 107 & 5.10 & 2.79 & 81 & 3.86 & 3.40 & 81 & 3.86 & 3.40 \\
\hline \multirow[t]{2}{*}{$\begin{array}{l}\text { Books \& Proc. } \\
\text { (Total publ.) }\end{array}$} & pre- & 109 & 5.19 & 4.19 & 109 & 5.19 & 4.19 & 85 & 4.05 & 3.71 \\
\hline & post- & 112 & 5.33 & 4.94 & 111 & 5.29 & 4.97 & 110 & 5.24 & 4.82 \\
\hline \multirow[t]{2}{*}{$\begin{array}{l}\text { Book \& Proc. } \\
\text { (Spanish, publ.) }\end{array}$} & pre- & 92 & 4.38 & 4.08 & 92 & 4.38 & 4.08 & 76 & 3.62 & 3.71 \\
\hline & post- & 98 & 4.67 & 4.49 & 97 & 4.62 & 4.51 & 96 & 4.57 & 4.33 \\
\hline
\end{tabular}


Table 1. (Continued)

\begin{tabular}{|c|c|c|c|c|c|c|c|c|c|c|}
\hline \multirow[b]{2}{*}{ VARIABLE } & \multirow[b]{2}{*}{ Period } & \multicolumn{3}{|c|}{ inXinN } & \multicolumn{3}{|c|}{ outXinN } & \multicolumn{3}{|c|}{ outXoutN } \\
\hline & & $\Sigma \mathrm{N}$ & Mean & SD & $\Sigma \mathrm{N}$ & Mean & SD & $\Sigma \mathrm{N}$ & Mean & SD \\
\hline \multirow[t]{2}{*}{$\begin{array}{l}\text { Book \& Proc. } \\
\text { (Foreign, publ.) }\end{array}$} & pre- & 17 & 0.81 & 1.03 & 17 & 0.81 & 1.03 & 9 & 0.43 & 0.68 \\
\hline & post- & 14 & 0.67 & 1.59 & 14 & 0.67 & 1.59 & 14 & 0.67 & 1.59 \\
\hline \multicolumn{11}{|l|}{ First authors } \\
\hline (Number) & post- & 584 & 27.81 & 5.27 & 557 & 26.52 & 5.19 & 555 & 26.43 & 5.26 \\
\hline \multicolumn{11}{|l|}{ Authors 1st MNCN } \\
\hline (Publ.) & post- & 655 & 31.19 & 10.98 & 544 & 25.90 & 8.14 & 655 & 31.19 & 10.98 \\
\hline \multicolumn{11}{|l|}{ Author lst non } \\
\hline \multirow[t]{2}{*}{ MNCN (Publ.) } & pre- & 1031 & 49.10 & 9.66 & 1040 & 49.52 & 9.50 & 600 & 28.57 & 7.30 \\
\hline & post- & 511 & 24.33 & 5.70 & 574 & 27.33 & 5.58 & 459 & 21.86 & 5.02 \\
\hline \multicolumn{11}{|l|}{ Authors 1st } \\
\hline \multirow[t]{2}{*}{ (\% MNCN, publ.) } & pre- & - & 28.29 & 8.23 & - & 26.67 & 7.66 & - & 39.43 & 11.92 \\
\hline & post- & - & 55.21 & 10.92 & - & 47.90 & 6.50 & - & 57.81 & 9.12 \\
\hline \multirow[t]{2}{*}{ Productivity } & pre- & - & - & - & 59.93 & 2.85 & 0.58 & 45.80 & 2.18 & 0.42 \\
\hline & post- & - & - & - & 42.36 & 2.02 & 0.28 & 44.06 & 2.10 & 0.42 \\
\hline \multicolumn{11}{|l|}{ Spanish } \\
\hline \multirow[t]{2}{*}{ (Publications) } & pre- & 1036 & 49.33 & 11.68 & 1018 & 48.48 & 11.21 & 751 & 35.76 & 10.46 \\
\hline & post & 1121 & 53.38 & 9.96 & 1074 & 51.14 & 11.00 & 1072 & 51.05 & 11.07 \\
\hline \multirow{3}{*}{$\begin{array}{l}\text { Catalonian } \\
\text { (Publications) }\end{array}$} & & & & & & & & & & \\
\hline & pre- & 235 & 11.19 & 6.24 & 235 & 11.19 & 6.24 & 218 & 10.38 & 5.86 \\
\hline & post & 6 & 0.29 & 0.56 & 6 & 0.28 & 0.56 & 6 & 0.29 & 0.56 \\
\hline \multirow{3}{*}{$\begin{array}{l}\text { Foreign languages } \\
\quad \text { (Publ.) }\end{array}$} & & & & & & & & & & \\
\hline & pre- & 172 & 8.19 & 3.08 & 170 & 8.10 & 3.24 & 25 & 1.19 & 1.21 \\
\hline & post- & 35 & 1.67 & 2.27 & 36 & 1.71 & 2.12 & 36 & 1.71 & 2.12 \\
\hline
\end{tabular}

Note. $-\Sigma \mathrm{N}$ refers to the summation of the different year values, which for variables such as number of authors, journals, or books and proceedings does not represent the number of different items. SD: Standard deviation. Group 1 (inXinN) considers all the Spanish entomologists. Group 2 (outXinN) includes only the Spanish scientists working in Spain, excluding those in exile. Group 3 (outXoutN) excludes those in exile and L. Navás, considered a statistical outlier.

the museum, including taking on the curatorial aspects of maintaining the collections. The members of these research groups on insects were engaged in basic zoological studies - morphology, systematics, faunistics - in both periods considered here, and their scientific contributions provide numerically comparable samples.

Many of the MNCN entomologists studied here were active during both periods, first within the JAE and later for the CSIC. This persistence facilitates analysis of the impact of the 
Table 2. Statistical Comparisons Between The Pre- (1915-1935) And Postwar (1940-1960) Periods.

\begin{tabular}{|c|c|c|c|c|}
\hline VARIABLE & TEST & inXinN & outXinN & outXinN \\
\hline \multirow[t]{2}{*}{ Publications (Total) } & U-test & $<0.01$ & $<0.01$ & 0.113 \\
\hline & $\Delta \%$ & -19.2 & -21.7 & +12.1 \\
\hline \multirow[t]{2}{*}{ Publications (Spanish editions) } & U-test & 0.068 & 0.062 & 0.464 \\
\hline & $\Delta \%$ & -12.8 & -12.9 & +3.7 \\
\hline \multirow[t]{2}{*}{ Publications (Foreign editions) } & U-test & $<0.01$ & $<0.01$ & 0.031 \\
\hline & $\Delta \%$ & -43.5 & -57.3 & +233.9 \\
\hline \multirow[t]{2}{*}{ Articles (Total journals) } & U-test & $<0.01$ & $<0.01$ & 0.162 \\
\hline & $\Delta \%$ & -21.0 & -23.6 & +10.3 \\
\hline \multirow[t]{2}{*}{ Articles (Spanish journals) } & U-test & 0.070 & 0.070 & 0.606 \\
\hline & $\Delta \%$ & -14.5 & -14.5 & +1.7 \\
\hline \multirow[t]{2}{*}{ Articles (Foreign journals) } & U-test & $<0.01$ & $<0.01$ & 0.020 \\
\hline & $\Delta \%$ & -45.0 & -59.8 & +291.5 \\
\hline \multirow[t]{2}{*}{ Articles (Governmental) } & U-test & $<0.01$ & $<0.01$ & $<0.01$ \\
\hline & $\Delta \%$ & +129.9 & +129.2 & +193.2 \\
\hline \multirow[t]{2}{*}{ Articles (Nongovernmental) } & U-test & $<0.01$ & $<0.01$ & $<0.01$ \\
\hline & $\Delta \%$ & -78.9 & -78.8 & -75.8 \\
\hline \multirow[t]{2}{*}{ Journals (Total number) } & U-test & $<0.01$ & $<0.01$ & $<0.01$ \\
\hline & $\Delta \%$ & -23.0 & -27.5 & +52.2 \\
\hline \multirow[t]{2}{*}{ Journals (Spanish, number) } & U-test & 0.722 & 0.722 & $<0.01$ \\
\hline & $\Delta \%$ & -4.8 & -4.8 & +30.3 \\
\hline \multirow[t]{2}{*}{ Journals (Foreign, number) } & U-test & $<0.01$ & $<0.01$ & 0.012 \\
\hline & $\Delta \%$ & -47.0 & -58.5 & +224.4 \\
\hline \multirow[t]{2}{*}{ Books \& Proceedings (Total publications) } & U-test & 0.800 & 0.742 & 0.402 \\
\hline & $\Delta \%$ & +2.7 & +1.9 & +29.4 \\
\hline \multirow[t]{2}{*}{ Books \& Proceedings (Spanish, publications) } & U-test & 0.889 & 0.939 & 0.341 \\
\hline & $\Delta \%$ & +6.6 & +5.5 & +26.2 \\
\hline \multirow[t]{2}{*}{ Books \& Proceedings (Foreign, publications) } & U-test & 0.235 & 0.235 & 0.890 \\
\hline & $\Delta \%$ & -17.3 & -17.3 & +55.8 \\
\hline \multirow[t]{2}{*}{ First authors (Number) } & U-test & 0.044 & 0.150 & 0.063 \\
\hline & $\Delta \%$ & +13.4 & +9.6 & +14.0 \\
\hline \multirow[t]{2}{*}{ First authors MNCN (Publications) } & U-test & $<0.01$ & $<0.01$ & $<0.01$ \\
\hline & $\Delta \%$ & +59.0 & +41.3 & +66.3 \\
\hline \multirow[t]{2}{*}{ First authors non MNCN (Publications) } & U-test & $<0.01$ & $<0.01$ & $<0.01$ \\
\hline & $\Delta \%$ & -50.5 & -44.8 & -23.5 \\
\hline \multirow[t]{2}{*}{ First Authors (\% MNCN, publications) } & U-test & $<0.01$ & $<0.01$ & $<0.01$ \\
\hline & $\Delta \%$ & +95.2 & +79.6 & +46.6 \\
\hline \multirow[t]{2}{*}{ Productivity } & U-test & - & $<0.01$ & 0.458 \\
\hline & $\Delta \%$ & - & -29.1 & -3.7 \\
\hline \multirow[t]{2}{*}{ Spanish (Publications) } & U-test & 0.178 & 0.392 & $<0.01$ \\
\hline & $\Delta \%$ & +8.2 & +5.5 & +42.8 \\
\hline \multirow[t]{2}{*}{ Catalan (Publications) } & U-test & $<0.01$ & $<0.01$ & $<0.01$ \\
\hline & $\Delta \%$ & -97.4 & -97.7 & -97.3 \\
\hline \multirow[t]{2}{*}{ Foreign languages (Publications) } & U-test & $<0.01$ & $<0.01$ & 0.802 \\
\hline & $\Delta \%$ & -79.6 & -78.9 & +43.7 \\
\hline
\end{tabular}

Note. - U-test: Probabilities after the nonparametric Mann-Whitney U-test for equal means. $\Delta \%$ : Percentage increment or decrement of the postwar period with respect to the prewar period. Groups analyzed as in Table 1. 
Civil War on science and of the subsequent change in the orientation of research in Spain. The work of scientists who took part in both the MNCN Section of Entomology and the IEE is representative of Spanish entomological investigation because these institutions were associated with Madrid's Central University, the main training center for this discipline in the country, although not the only one. ${ }^{15}$

Other state-owned institutions active in entomological research were the universities and the museums, particularly that in Barcelona. Other scientific organizations that had specialized libraries but were mostly without laboratories or collections were the royal science academies, mainly the Real Academia de Ciencias Exactas, Físicas y Naturales in Madrid, the Reial Acadèmia de Ciències i Arts de Barcelona, and the Real Academia de Ciencias de Zaragoza. Societies not belonging to the public sector and that engaged in natural history studies were also active; the main one devoted to entomology was the Real Sociedad Española de Historia Natural.

\section{DESCRIPTIVE RESULTS}

The general trend of Spanish entomology, as indicated by the number of publications per year, is presented in Figure 3, and the basic statistics for the variables analyzed are given in Table 1. Statistical comparisons between the pre- (1915-1935) and postwar (1940-1960) periods are shown in Table 2.

\section{Publications}

If we include the contributions by Navás, the net cost of the Civil War represented in the medium term a significant decrease: about 20 percent in total publication production per year. However, as previously indicated, it seems more realistic to remove the "Navás effect," treating this author as an outlier, and in this case the mean annual number of publications (12 percent postwar increase) does not differ significantly between the pre- and postwar periods. Similar results are obtained when we look at publications in foreign venues in the two periods, particularly because Navás was more likely than his counterparts to publish in non-Spanish media. Without the Navás effect, the differences are not significant, in spite of a large postwar increment because most foreign publications concentrate in the late 1950s. On the contrary, the mean number of annual publications in national editions did not differ significantly in the two periods under any of the cases.

In the years immediately before the war a clear reduction in the number of publications can be observed; the recovery process that followed afterward is almost a mirror image. ${ }^{16}$

\section{Journal Articles}

Analysis of journal articles published per year shows similar trends as the number of publications. The mean of the total number of articles per year shows a significant postwar decrease of about 22 percent if Navás is included and no significant difference ( 10 percent postwar increase) after removing Navás. The comparison of publications in Spanish and foreign journals (see Figure 4) in the two periods is similar to results seen for total publications. However, if we compare the articles published by governmental versus nongovernmental journals (see Figure 5), very large differences are found, with significant increases in state-funded publications.

\footnotetext{
${ }^{15}$ Barreiro, El Museo Nacional de Ciencias Naturales (1771-1935) (cit. n. 13).

${ }^{16}$ For instance, in the nine ordinal years before (inverted, 1938-1930) and after (1938-1946) the war's climax, the total publications (exiles excluded and Navás included) adjust accurately to linear regression with slope $0.719\left(\mathrm{R}^{2}=0.957\right)$.
} 


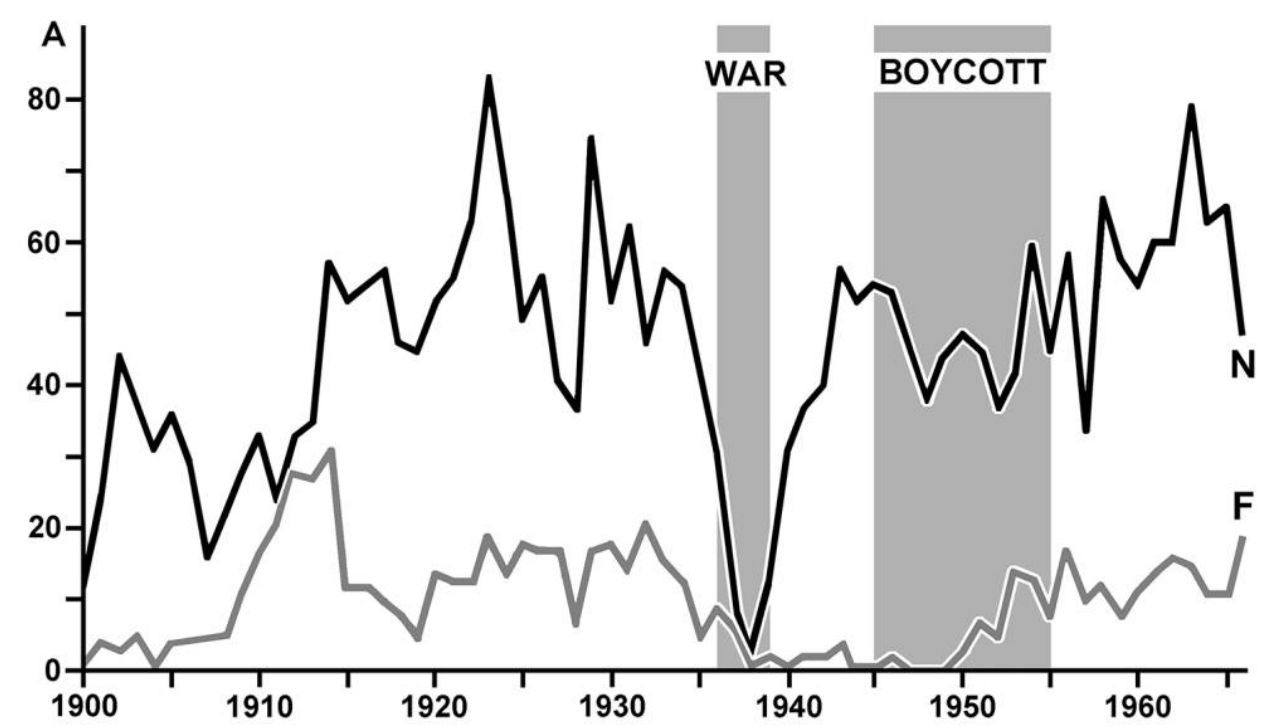

Figure 4. Number of Spanish entomological articles (A) per year, differentiating national (N, black line) and foreign (F, gray line) journals. The Civil War period and the years of the United Nations boycott of Spain are indicated.

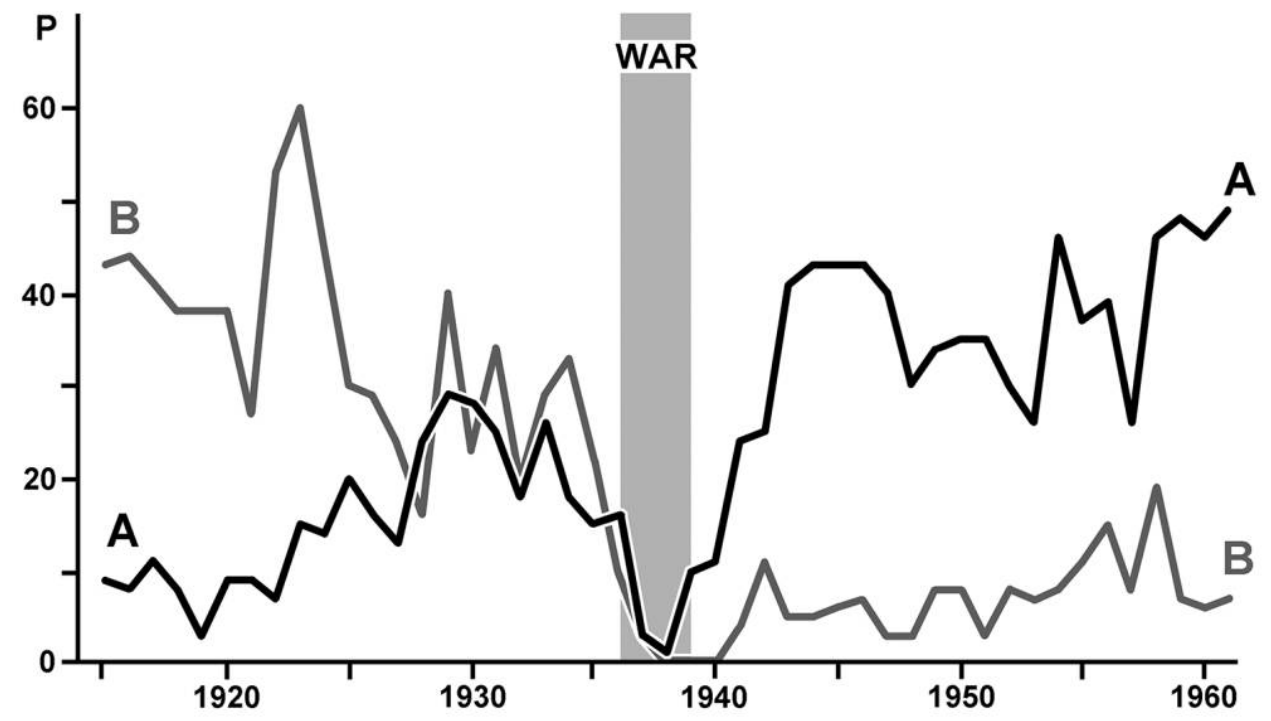

Figure 5. Comparison in number of entomological articles $(\mathrm{P})$ per year published in governmental (A, black line) and nongovernmental (B, gray line) Spanish journals. 


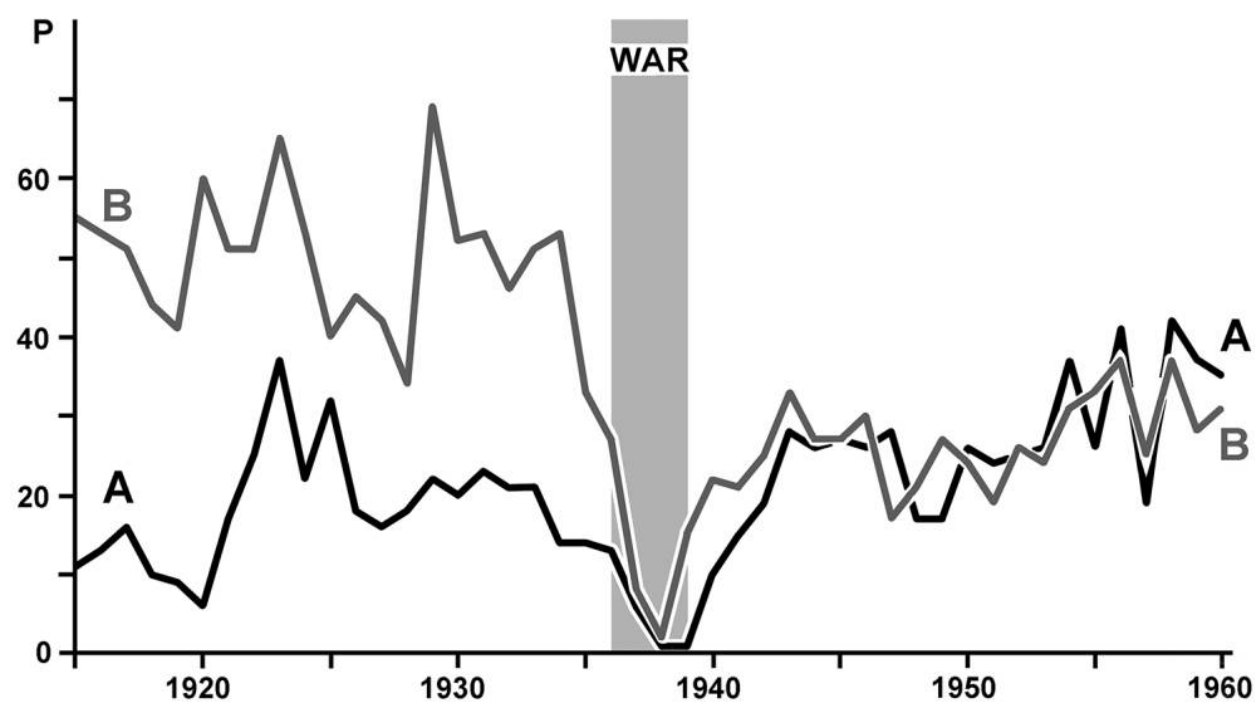

Figure 6. Comparison in number of entomological publications $(\mathrm{P})$ per year by scientists affiliated (A, black line) or not affiliated (B, gray line) with the major Spanish research institutions (the JAE and the CSIC).

\section{Journals}

The total number of journals used by entomologists per year shows a significant mean decrease (ca. 25 percent) in the postwar period when Navás is included and a large (52 percent) increase when his contributions are excluded. However, the number of Spanish journals used before and after the war does not differ when including Navás; it shows a significant increase (30 percent) when this author is not considered. On the other hand, the differences with respect to foreign journals are clear (minus 47-58 percent) with Navás included, while a nonsignificant increment results if the Navás effect is removed.

\section{Books and Proceedings}

With regard to the number of scientific publications other than journals-such as books, monographs, chapters, or entries in congress proceedings - there are no significant differences between the pre- and postwar periods for any of the different groups studied.

\section{Authors}

The number of different first authors per year shows slight nonsignificant increases after the war in the three groups analyzed. However, the group of scientists affiliated with the National Museum of Natural Sciences (either the Department of Entomology or the Spanish Institute of Entomology) shows a significant shift (see Figure 6), becoming proportionally much larger after the war. The mean annual productivity of entomologists is significantly lower after the war if we include Navás but similar to prewar output if we exclude the contributions of this author.

Stability of scientists as individuals and generational replacement of the entomological research community, as estimated for twelve-year periods (see Table 3), shows a different pattern before and after the war (see Figure 7), as well as unique values for the immediate pre- and postwar comparison (1930-1935 vs. 1940-1945). Including Navás, the degree of abandonment 
Table 3. Stability and Generational Replacement in the Spanish Community of Entomologists

\begin{tabular}{|c|c|c|c|c|c|c|c|c|}
\hline \multicolumn{2}{|l|}{ PERIOD } & A & $\mathrm{R}$ & $\mathrm{C}$ & $\mathrm{A}+\mathrm{R}+\mathrm{C}$ & A\% & B\% & $\mathrm{C} \%$ \\
\hline \multicolumn{2}{|l|}{ P01 } & 9 & 10 & 30 & 49 & 18,37 & 20,41 & 61,22 \\
\hline \multicolumn{2}{|l|}{ P02 } & 7 & 9 & 30 & 46 & 15,22 & 19,57 & 65,22 \\
\hline \multicolumn{2}{|l|}{$\mathrm{P} 03$} & 4 & 10 & 33 & 47 & 8,51 & 21,28 & 70,21 \\
\hline \multicolumn{2}{|l|}{ P04 } & 4 & 11 & 36 & 51 & 7,84 & 21,57 & 70,59 \\
\hline \multicolumn{2}{|l|}{ P05 } & 7 & 12 & 34 & 53 & 13,21 & 22,64 & 64,15 \\
\hline \multicolumn{2}{|l|}{ P06 } & 9 & 15 & 32 & 56 & 16,07 & 26,79 & 57,14 \\
\hline \multicolumn{2}{|l|}{ P07 } & 9 & 17 & 30 & 56 & 16,07 & 30,36 & 53,57 \\
\hline \multicolumn{2}{|l|}{ P08 } & 9 & 19 & 33 & 61 & 14,75 & 31,15 & 54,10 \\
\hline \multicolumn{2}{|l|}{ P09 } & 10 & 16 & 34 & 60 & 16,67 & 26,67 & 56,67 \\
\hline \multicolumn{2}{|l|}{$\mathrm{P} 10$} & 6 & 8 & 40 & 54 & 11,11 & 14,81 & 74,07 \\
\hline \multicolumn{2}{|l|}{ Pll } & 7 & 5 & 40 & 52 & 13,46 & 9,62 & 76,92 \\
\hline \multicolumn{2}{|l|}{$\mathrm{P} 12$} & 9 & 8 & 39 & 56 & 16,07 & 14,29 & 69,64 \\
\hline \multicolumn{2}{|l|}{$\mathrm{Pl} 3$} & 9 & 10 & 40 & 59 & 15,25 & 16,95 & 67,80 \\
\hline \multicolumn{2}{|l|}{ P14 } & 10 & 9 & 41 & 60 & 16,67 & 15,00 & 68,33 \\
\hline \multicolumn{2}{|l|}{ P15 } & 11 & 8 & 39 & 58 & 18,97 & 13,79 & 67,24 \\
\hline \multicolumn{2}{|l|}{ P16 } & 12 & 9 & 38 & 59 & 20,34 & 15,25 & 64,41 \\
\hline \multicolumn{2}{|l|}{$\mathrm{Pl}$} & 8 & 10 & 36 & 54 & 14,81 & 18,52 & 66,67 \\
\hline \multicolumn{2}{|l|}{ P18 } & 10 & 9 & 37 & 56 & 17,86 & 16,07 & 66,07 \\
\hline \multicolumn{9}{|c|}{ STATISTICS } \\
\hline \multicolumn{2}{|l|}{$\mathrm{N}$} & 18 & 18 & 18 & 18 & 18 & 18 & 18 \\
\hline \multicolumn{2}{|l|}{ Mean } & 8,33 & 10,83 & 35,67 & 54,83 & 15,07 & 19,71 & 65,22 \\
\hline \multicolumn{2}{|l|}{ Maximum } & 12 & 19 & 41 & 61 & 20,34 & 31,15 & 76,92 \\
\hline \multicolumn{2}{|l|}{ Minimum } & 4 & 5 & 30 & 46 & 7,84 & 9,62 & 53,57 \\
\hline \multicolumn{2}{|l|}{$\mathrm{SD}$} & 2,17 & 3,63 & 3,79 & 4,49 & 3,32 & 6,00 & 6,54 \\
\hline \multicolumn{9}{|l|}{ GROUPS } \\
\hline \multirow[t]{2}{*}{ inXinN } & & 15 & 10 & 34 & 59 & 25,42 & 16,95 & 57,63 \\
\hline & $\mathrm{Z}$ & 3,07 & $-0,23$ & $-0,44$ & 0,93 & 3,12 & $-0,46$ & $-1,16$ \\
\hline \multirow[t]{2}{*}{ outXinN } & & 18 & 11 & 29 & 58 & 31,03 & 18,97 & 50,00 \\
\hline & $\mathrm{Z}$ & 4,46 & 0,05 & $-1,76$ & 0,71 & 4,82 & $-0,12$ & $-2,33$ \\
\hline
\end{tabular}

Note. $-A, R$, and C: Number of scientists active only in the first (A, abandonment), second ( $\mathrm{R}$, recruitment), or in both (C, continuity) parts of each period. P01 to P18 are the different periods in which a reference population was estimated (see "Methods, Variables, and Sample Selection"). SD: Standard deviation. For the period immediately before and after the war, not included in the reference population, Group inXinN considers all the Spanish entomologists and Group outXinN only those working in Spain, excluding the exiles. Z: Standardized Z scores corresponding to the inXinN and outXinN values. 


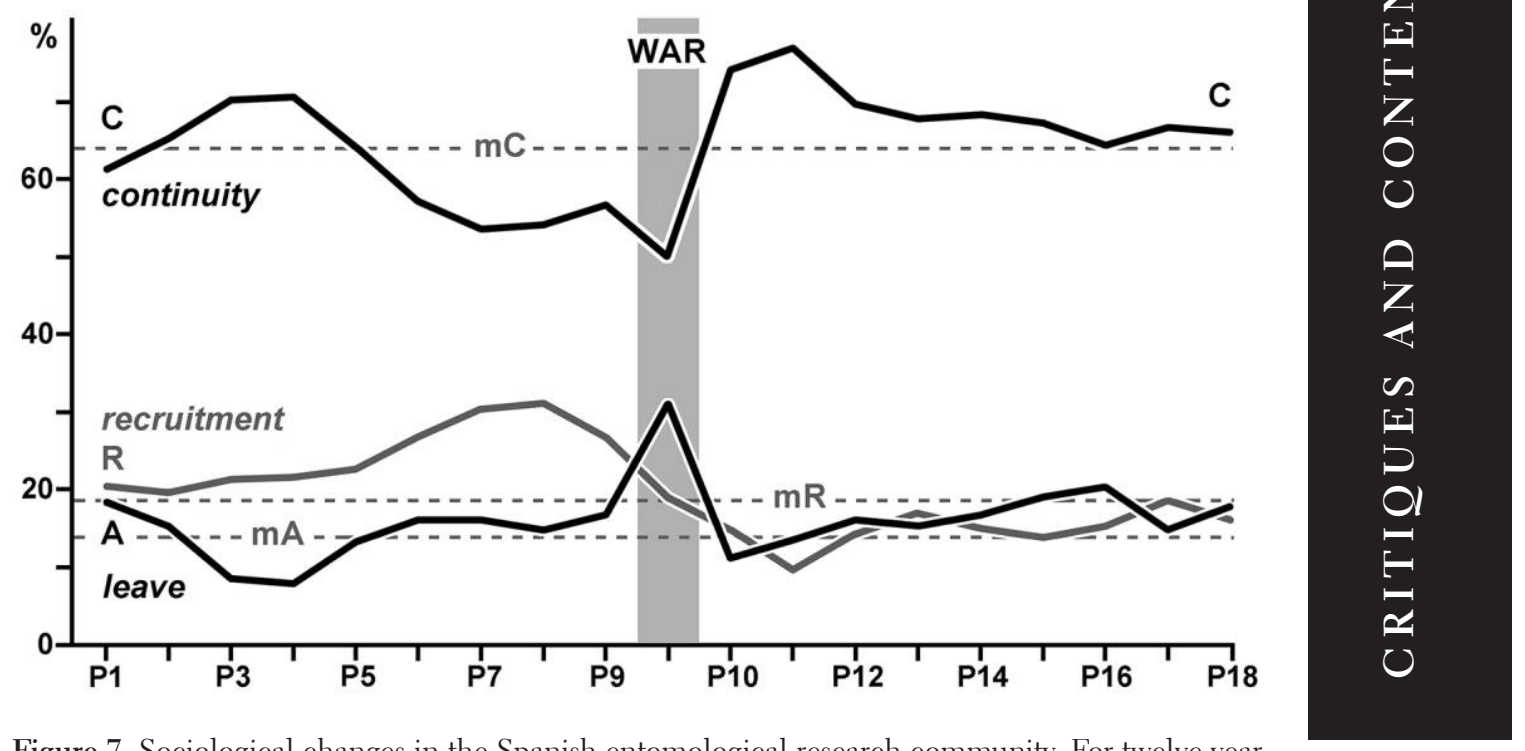

Figure 7. Sociological changes in the Spanish entomological research community. For twelve-year periods (Pl to P18), comparisons are made between the first and second six-year half-periods in the percentages of scientists active only in the first (A, abandonment), only in the second ( $\mathrm{R}$, recruitment), or in both (C, continuity). Starting from 1915-1926, the periods are defined by displacing one year (e.g., 1916-1921, 1917-1922) until 1923-1934 and from 1940-1951 to 1948-1959, plus the period (grey column) 1930-1935 and 1940-1945 taken as a substitute to avoid the Civil War (1936-1939) inactivity. Dashed lines indicate the mean values $(\mathrm{mA}, \mathrm{mC}, \mathrm{mR})$, not including the war period.

of the field is high, either considering or excluding exiles, while recruitment and continuity reach normal historical levels, pointing in this moment to an unusually large number of scientists leaving active research and ceasing to publish.

\section{Languages}

Of the different languages spoken in Spain, in the periods studied only one publication has been recorded in Galician and none in Basque. There is no difference in the number of publications in Spanish during the pre- and postwar years, but there is a slight decrease in the use of Catalan sensu lato (including Balearic and Valencian) during the prewar period and a sharp reduction after the war, from 16.5 percent to 0.5 percent (see Figure 8); this language reappears at the end of the period.

French was by far the foreign language most frequently used, up to 62.6 percent before and 80.6 percent after the war. Other languages were in only sporadic use. ${ }^{17}$ Comparisons in the number of publications in foreign languages between the two periods show a significant decrease if Navás is included, but there is no difference otherwise.

\section{INTERPRETATION OF RESULTS AND CONCLUSIONS}

The scientific research framework requires at least the following main components: the human factor (scientists, technical and supporting staff); instrumentation and research facilities,

\footnotetext{
${ }^{17}$ Among the languages in sporadic use are English (3.5 percent before the war and 8.3 percent after), German (9.4 percent and 8.3 percent), and Italian ( 8.2 percent and 2.8 percent)
} 


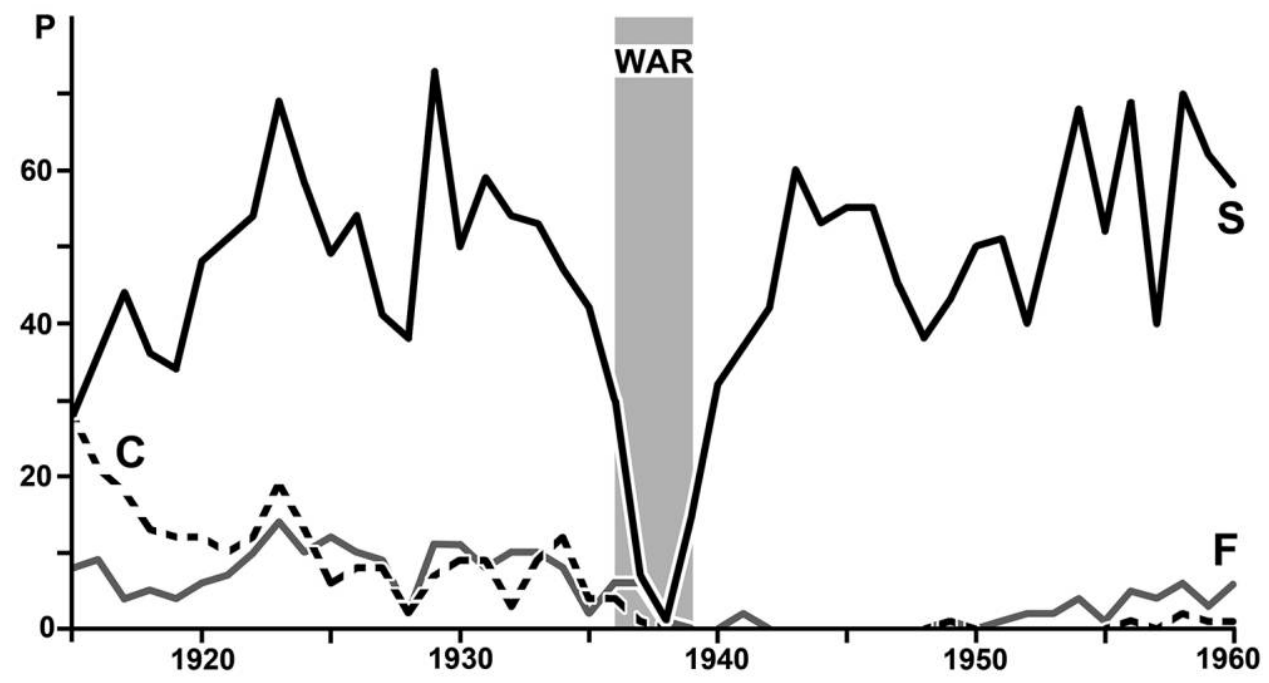

Figure 8. Number of entomological articles per year (1915-1960), differentiated by language: Spanish ( $\mathrm{S}$, black line), Catalan $(\mathrm{C}$, dashed line), and foreign ( $\mathrm{F}$, gray line). The Civil War period is indicated.

including specialized libraries (entomology also requires access to comparative taxonomic collections); economic and financial support for projects and personnel; and publications, meetings, and media to present research results. The circumstances of the Spanish Civil War did not significantly alter the research-related material factor. The main libraries, laboratories, and comparative collections were not destroyed as a result of the military conflict. Similarly, the economic component was not drastically altered. ${ }^{18}$ As we have seen, changes in the number of scientists employed were rather small, and entomological projects require comparatively low budgets. However, other factors involved in research outcome were affected by the war to an important extent, and their alterations can be interpreted and evaluated using a quantitative framework.

Looking first at the human factor: a total of 130 and 132 scientists were active in Spain, publishing as first authors, in the twenty-one-year pre- and postwar periods, respectively, and 66 and 62 were active in the six-year periods just before and just after the war (1930-1935 vs. 1940-1945). The exile component is numerically not important, with only one entomologist returning to Spain and seven leaving the country as a consequence of the war.

The Civil War was preceded by a period of major social instability, which corresponds with the advent of the Second Republic in 1931; this instability is evident in entomological production. ${ }^{19}$ For this reason, in order to summarize the overall situation in the immediate postwar period we have used as a reference value the mean publication production during the period 1920-1929. Figure 9 shows (as percentages of the 1920-1929 mean) that the total number of publications (excluding exiles) increased very quickly after the war. However, the

\footnotetext{
${ }^{18}$ Imanol Herreros Chandro, "La ciencia de la dictadura: El sistema nacional de I+D durante el franquismo (1939-1975)," Revista de Claseshistoria, 2013, article 357.

${ }^{19}$ On the social instability of the Second Republic years see, e.g., Paul Preston, Coming of the Spanish Civil War: Reform, Reaction, and Revolution in the Second Republic, 2nd ed. (London: Routledge, 1994); and Henry Buckley, The Life and Death of the Spanish Republic (London: Tauris, 2013).
} 


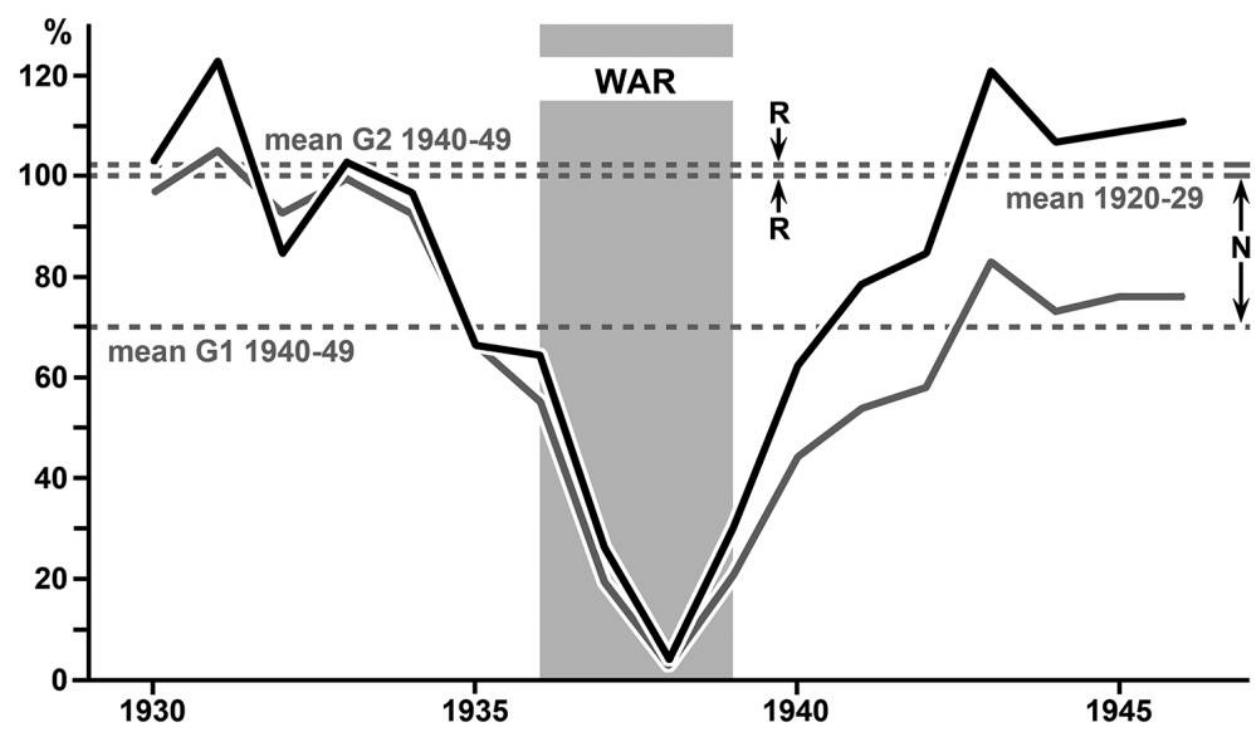

Figure 9. Decline and recovery rates close to the war, as shown by the percentages of the number of annual publications with respect to the 1920-1929 mean. The gray line excludes exiles but not Navás (G1). The black line excludes exiles and Navás (G2). N and R arrows indicate the differences between the reference mean and the 1940-1949 means of the groups G1 and G2, respectively.

level of recovery that was reached is different depending on whether Navás is included in the comparison. Excluding Navás as a singular outlier, the mean 1940-1949 value is very similar to the reference value, and as early as 1943 the annual production was actually higher, implying a complete recovery of research output in a very short time. The less realistic situation in which Navás is included in the comparison points to a different result; because he passed away in 1938 he contributed almost no publications after the war, and the mean 1940-1949 value is about 20 percent lower than the reference value.

Whereas in terms of total production the research system emerged from the war without significant evidence of deterioration, or experienced only a moderate impact, we have found important differences in some variables that can be related to social or organizational factors. In the first place, a clear decrease is detected in both absolute and relative numbers of publications in foreign venues, associated with lesser use of foreign languages. This decrease may perhaps be due to international circumstances at the time, including World War II and the United Nations boycott of Spain up to 1955, which was enforced to varying degrees.

Other differential aspects point, rather, to the altered structure of scientific organization in Spain. These modifications can be ascribed to the relative importance of two particular characteristics: more publications coming directly from government-run institutions and more first authors that were employed by or associated with the state administration. There is a clear decline after the war in research outside the public sector, and local scientific organizations and societies recovered much more slowly, particularly if they did not receive government subsidies. ${ }^{20}$ This fact also explains the near-disappearance of Catalan in the entomological

\footnotetext{
${ }^{20}$ Josep M. Camarasa, Cent anys de passió per la natura: Una història de la Institució Catalana d'Història Natural (1899-1999) (Barcelona: Institució Catalana d'Història Natural, 2000).
} 
literature until the late 1950s, since Spanish was with very few exceptions the only language used by the government.

In our analysis of actual scientific production, traditional accounts of the history of administration, legislation, ideologies, and personal biographies are considered a black box. Available data of this sort are both excessively incomplete and unstructured, and it is still early to perform any analysis of causality. However, it is surprising to see how a minor zoological research specialty can reflect changes and tendencies in the complex social dynamics of science. Our example indicates that an abrupt alteration in social circumstances will have a rather minor impact and that scientific production will recover quickly, under any ideological scenario, as long as there is significant research continuity among individual scientists ( 50 percent, at least), material facilities are available, and there is a minimum of governmental financial support for both. Other cases, in which the circumstances are different, should be analyzed quantitatively in order to build a comparative framework. ${ }^{21}$

${ }^{21}$ Possible examples are Germany after World War II or China after the Cultural Revolution. 